\title{
Atlantic Forest Fragmentation Analysis and Landscape Restoration Management Scenarios
}

\author{
Lisiane Zanella ${ }^{1,2}$, Rosângela Alves Tristão Borém ${ }^{1}$, \\ Carolina Gusmão Souza ${ }^{1,2}$, Helena Maria Ramos Alves ${ }^{3 *}$ \& Flávio Meira Borém ${ }^{4}$
}

\author{
${ }^{1}$ Setor de Ecologia, Departamentode Biologia, Universidade Federal de Lavras - UFLA, Lavras, MG, Brasil \\ ${ }^{2}$ GeoSolos, Empresa de Pesquisa Agropecuária de Minas Gerais - EPAMIG, Belo Horizonte, MG, Brasil \\ ${ }^{3}$ Embrapa Café, Parque Estação Biológica, Brasília, DF, Brasil \\ ${ }^{4}$ Departamento de Engenharia, Universidade Federal de Lavras - UFLA, Lavras, MG, Brasil
}

\begin{abstract}
The goals of this research were to analyze the fragmentation of the Atlantic Forest and to create landscape management scenarios for the municipality of Carmo de Minas, MG, Brazil. We used landscape metrics to analyze the fragmentation process of the study area, which was historically exploited for agropastoral activities. Future scenarios were modeled to represent the potential restoration of the environment based on the behavior of the natural vegetation units. The natural vegetation in the study area is highly fragmented, and the environmental integrity of its remnants is severely threatened. The management scenarios showed how the restored natural units behave in the landscape as well as the isolation and connectivity between them. Using these models, future dynamics of the landscape can be predicted. Two important actions for the conservation of the remaining natural vegetation were identified: the maintenance of secondary forest and the restoration of permanent preservation areas.
\end{abstract}

Key words: Landscape Metrics, Landscape Ecology, Management Scenarios.

\section{Introduction}

The Atlantic Forest originally covered a large extent of the Brazilian territory. However, this forest is now highly fragmented and is composed of landscapes with low-diversity habitats in very small, isolated patches (Ribeiro et al. 2011). Currently, only $12 \%$ of natural Brazilian Atlantic Forest remains in small $(84 \%<50 \mathrm{ha})$ and scattered (mean isolation is $1440 \mathrm{~m}$ ) patches, of which approximately half are less than $100 \mathrm{~m}$ from any edge (Ribeiro et al. 2011).

Forest fragmentation may be broadly defined as the process by which a continuous area of habitat is reduced in size and divided into two or more vegetation patches that are separated by their surroundings or by a matrix of habitats different from the original habitats (Fahrig 2003). Fragmentation can affect the spatial structure and ecological processes of the natural communities present in the landscape (Saunders et al. 1991). According to the matrix conditions, abiotic, direct biotic, or indirect biotic changes can affect plant and animal communities (Murcia 1995), and influence the effective isolation of habitat patches, rendering them

\footnotetext{
${ }^{\star}$ Send correspondence to: Helena Maria Ramos Alves Embrapa Café, Parque Estação Biológica, Av. W3 Norte, Edifício Sede Embrapa, Sala 307, CEP 70770-901, Brasília, DF, Brasil

e-mail: helena.alves@embrapa.br
}

more or less isolated than simple distance would indicate (Ricketts 2001).

Although highly dependent on the wider landscape context (Norris 2008), the maintenance of natural vegetation patches and corridors in fragmented landscapes is very important in promoting connectivity, reducing patch isolation and ensuring the persistence of native species diversity (Gardner 2010). Moreover, they are sources of propagules that promote the restoration of the flow of organisms, seeds, and pollen grains among the patches and the areas to be restored (Kageyama et al. 2003).

Landscape connectivity, a measure of the capacity of the landscape to facilitate biological flows among habitat patches (Fischer \& Lindenmayer 2007), is highly affected by landscape fragmentation, reflecting in the increase of patch isolation (Fahrig 2003; Fischer \& Lindenmayer 2007). Isolation means how spatially inaccessible a habitat patch is to dispersing organisms (Bender et al. 2003). This distance between patches results in the functional isolation of various populations that are subject to local extinction events with no possibility of recolonization, regionally decreasing the chances of the species' persistence. According to Boscolo et al. (2008), the movement of some bird species can be severely impaired in landscapes with patches that are far apart. 
On the other hand, a high structural connectivity favors the conservation of the local biodiversity. This is considered positive from an ecological point of view because it aids in the process of recolonization after local extinction and in the maintenance of metapopulations in fragmented landscapes (Metzger 2006).

Thus, landscape structure, which considers the composition and spatial arrangement of landscape features, has been used to infer the spatial and temporal integrity of key ecological processes for biodiversity maintenance (Fahrig 2003). The metrics used in the study of the landscape consist of a set of statistical tools used to quantify the composition and spatial configuration of landscapes, to evaluate and compare different landscapes, and to identify differences and determine functional relations between the processes and patterns within them (Turner \& Gardner 1990). The use of these metrics makes it possible to diagnose current problems, estimate future influences, and indicate the changes necessary to maintain the natural balance.
We expected that conserving secondary forest and restoring Permanent Protected Areas in the current landscape reduce structural isolation among natural vegetation patches. Also, the presence of small patches reduces patch isolation. Therefore, the objectives of this study were twofold: (1) to evaluate the forest fragmentation, average connectivity and isolation of the habitat patches at landscape scale of a highly fragmented region; and (2) to develop landscape management models to predict future scenarios including restored riparian forests and secondary vegetation and then infer about ecological restoration strategies based on the behavior of landscape units.

\section{Material and Methods}

\section{Study area}

The study area comprises the municipality of Carmo de Minas (Figure 1), located in the southern physiographic zone of Minas Gerais state at $22^{\circ} 07^{\prime} 21^{\prime \prime} \mathrm{S}$ and $45^{\circ} 07^{\prime} 45^{\prime \prime} \mathrm{W}$, which is part of the Mineiro Plateau in the Rio Grande basin

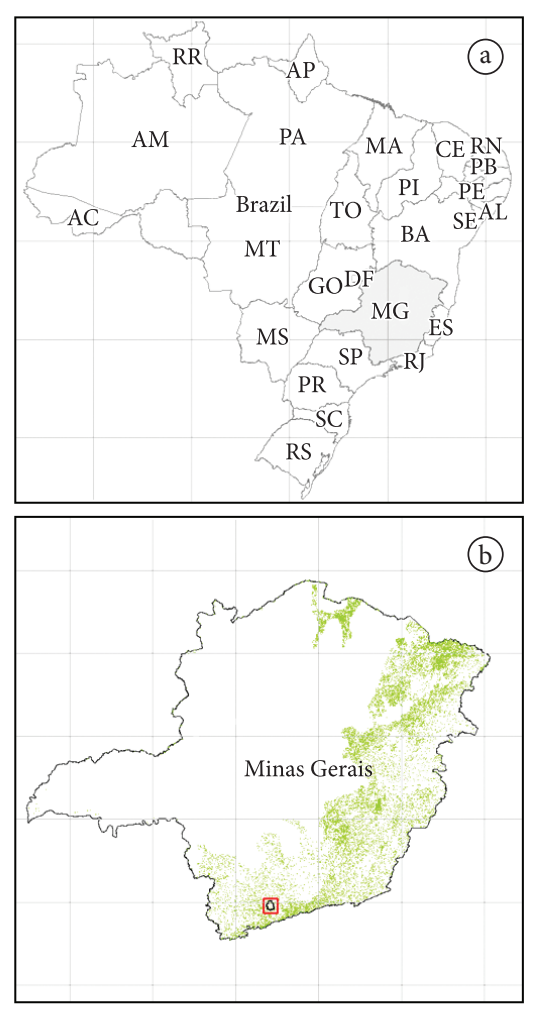

Legend

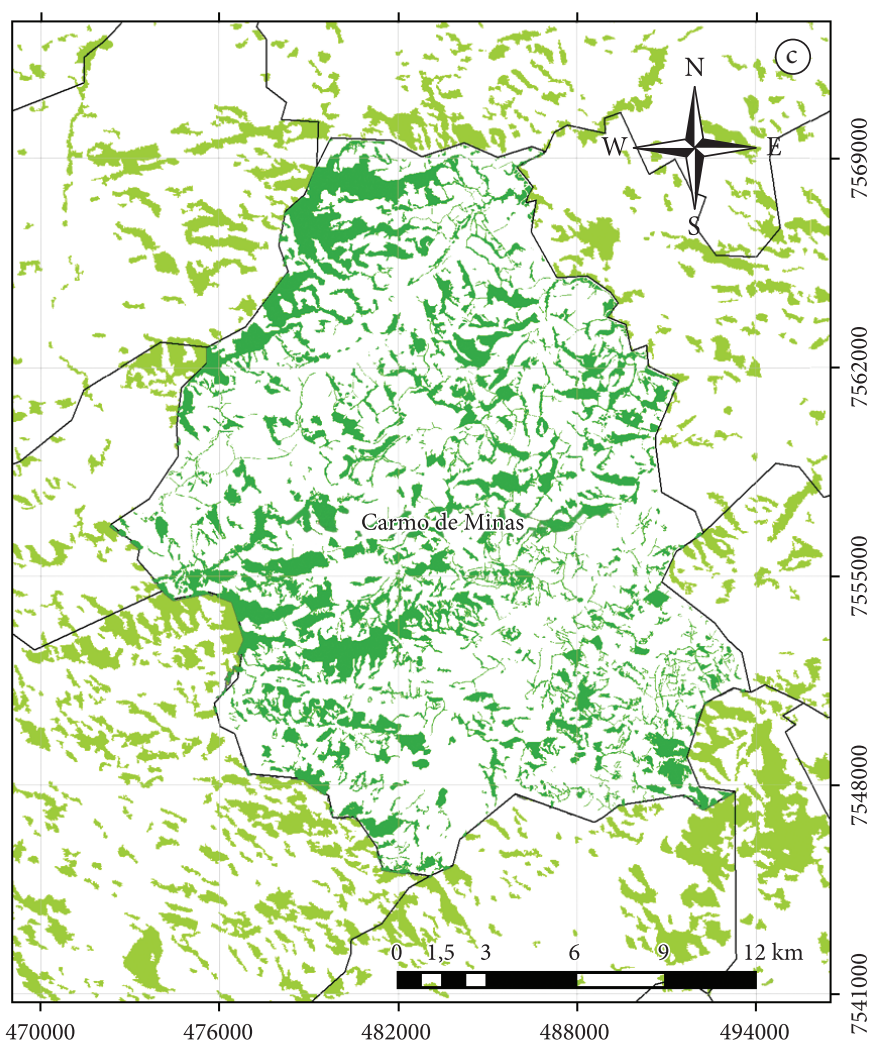

470000

476000

Atlantic Forest remnants mapped in this study

Atlantic Forest remnants (Scolforo \& Carvalho, 2006)

Carmo de Minas

Figure 1. Map of the study area ("Carmo de Minas"). a) State of Minas Gerais in the Southeast of Brazil. b) Atlantic Forest remnants of Minas Gerais mapped in 2009 (light green) (Scolforo \& Carvalho 2006). The red box indicates the study area in the South of Minas Gerais. c) Atlantic Forest remnants of Minas Gerais mapped in 2009 (light green) (Scolforo \& Carvalho 2006) and Atlantic Forest remnants mapped in this study (dark green). 
(IBGE 2009). This municipality has 32332 ha, with a central altitude of $960 \mathrm{~m}$, average annual temperature of $19.1^{\circ} \mathrm{C}$, and average annual precipitation of $1568 \mathrm{~mm}$ (IBGE 2009). The climate is temperate with dry winters ( $\mathrm{Cwb}$ ), and the region is composed of subtropical highlands according to the Köppen classification system (Martins 2000). The original vegetation is composed by dense broadleaf upper montane forest, mixed broadleaf upper montane forest, rocky outcrops, and high-altitude fields (Veloso et al. 1991).

\section{Land cover and permanent protected areas}

A land cover map was obtained by the visual interpretation of a $2.5 \mathrm{~m}$ resolution HCR SPOT image acquired in 2008. Visual interpretation was done by using the SPRING 5.1.5 GIS (Câmara et al. 1996). We mapped three land use classes: i) natural vegetation: old growth secondary forest remnants, ii) secondary forest: early growth secondary forest patches on abandoned cropland and pasture, and iii) other uses. A field survey was carried out to guarantee high map accuracy, which was accessed by the Kappa index (0.92), considered excellent (Cohen 1960).

Brazilian environmental legislation defines that strip marginal vegetation waterways and heads of rivers must be protected in order to guarantee water quality. These areas are known as Permanent Protected Areas (PPA), and should be obtained by defining a buffer zone of 30 to $50 \mathrm{~m}$ on both sides of the hydrographic features within the study area.

\section{Landscape analysis for current and management scenarios}

We reclassified the land cover map into a two class map: natural vegetation and matrix. Natural vegetation included only natural vegetation, and other classes were assigned to the matrix class. This map has $5 \mathrm{~m}$ spatial resolution, and was converted to ASCII format. Following the Ribeiro et al. (2009) approach, we calculated the area of natural vegetation patches and classified them into five classes: $<0.5,0.5$ to $1.0,1.0$ to $2.5,2.5$ to 10.0 , and 10.0 to 950.0 . Subsequently, we removed the natural vegetation patches along with the smallest patch size in several steps. We obtained 5 files beginning by eliminating those patches smaller than 0.5 ha and continuing to eliminate the larger ones until only patches larger than 10 ha remained. After, we calculated the nearest-neighbor mean distance (ENN_MN; m) using FRAGSTATS program (McGarigal \& Marks 1995).

We developed two landscape management scenarios to verify the isolation among patches into potential scenarios of natural vegetation restoration. The first scenario was based on the incorporation of secondary forests (VSF), and the second was based on the incorporation of reforested PPAs (VPPA). To estimate mean isolation, we used the nearest-neighbor mean distance $(\mathrm{m})$, as a measure of the structural isolation between patches.
We also calculated the following metrics for management scenarios and current natural vegetation: i) PLAND, or the percentage of forest cover (\%) used to estimate the remaining forest area; ii) NP, or number of patches, used to measure the fragmentation degree in the study area; iii) AREA_MN, or the mean patch area (ha), that may be related to biological features such as the minimum size requirement for a patch before a given species will occupy or use it as habitat; iv) LPI, or larger patch index (\%), that is the portion of the study area composed by the largest patch. We calculated all metrics using FRAGSTATS program.

\section{Data analysis}

We used the 2.14.0 version of $\mathrm{R}$ language ( $\mathrm{R}$ Development Core Team 2011) to perform a Pearson chi-squared $\left(\chi^{2}\right)$ test to verify if small patches reduce mean isolation in the landscape. We also compared the management scenarios to the current natural vegetation landscape, and evaluated the contribution of secondary forest and the PPAs to enhance the amount of natural vegetation and reduce patch isolation. For all data processing the actual vegetation was considered as observed frequency and the management scenarios as expected frequencies. The two management scenarios were also compared. $\mathrm{P}$ values below 0.05 were considered statistically significant.

\section{Results}

\section{The analysis of landscape fragmentation}

We observed that natural vegetation occupies 8545 ha $($ PLAND $=26.5 \%)$ and is distributed in 829 units with an average patch size of 12.8 ha (AREA_MN). The largest forest patch has $829.8 \mathrm{ha}(\mathrm{LPI}=2.6 \%)$ and we verified that the mean distance from the nearest neighbor (ENN_MN) is $55.3 \mathrm{~m}$.

We verified that $86.3 \%$ of the mapped patches are smaller than 10 ha and occupy only $16.6 \%$ of the Atlantic Forest area from the municipality of Carmo de Minas. The largest patches in this area, in the class of 10.0 to 950.0 ha, are few (42 patches) but together occupy the largest area of natural vegetation $(83.6 \%)$.

We observed a significant increase in the average isolation when the patches smaller than 2.50 ha were removed from the landscape. The landscape then had an average distance of $125.4 \mathrm{~m}$ among the patches of natural vegetation.

\section{The landscape management scenarios}

VPPA management scenario increased PLAND to 10592 ha (32.9\%), whereas under the VSF scenario, the natural vegetation would achieve a total area of 11762 ha (36.5\%). These values were not significantly different $\left(\chi^{2}=1.598\right.$, $P=0.450)$. 
Regarding habitat fragmentation, the NP was reduced by $20 \%$ in the VSF scenario and by $5.7 \%$ in the VPPA $\left(\chi^{2}=15.651, P<0.001\right.$; Figure 2).

LPI and AREA_MN showed no significant increase between the current scenario and management scenarios $\left(\chi^{2}=0.029\right.$, $P=0.985$ and $\chi^{2}=1.052, P=0.591$, respectively). ENN_MN showed significant reductions of $32 \%$ for VSF scenario and $50 \%$ for VPPA $\left(\chi^{2}=9.653, P=0.0080\right.$; Figure 3$)$.

\section{Discussion}

\section{The analysis of landscape fragmentation}

We found that within Carmo de Minas municipality the natural vegetation occupies $20 \%$ more of the landscape than is indicated by the Brazilian Forest Code (Brasil 1965). However, this proportion is under the thresholds suggested by Andrén (1994) and Metzger \& Décamps (1997) (30\% and $40 \%$, respectively) because fragmentation effects are determined mainly by the size of patches and their isolation in landscapes with a lower proportion of similar habitat.

We observed that natural vegetation is highly fragmented as a result of the high number of forest patches in relation to the total area occupied by this class. These data can be considered to be negative from an environmental perspective when compared to the results of another study also using landscape metrics in the state of Minas Gerais, in which AREA_MN was 30.6 ha (Calegari et al. 2010). However, in the south of Brazil, Cemin et al. (2009) found average patch sizes of 4.53 ha for mixed broadleaf forest patches and 5.44 ha for deciduous forest patches. For the whole Atlantic Forest landscape, $83.4 \%$ of patches are smaller than 50 ha according to estimates by Ribeiro et al. (2011). Therefore, although the areas compared above have different histories of clearing and land occupation, AREA_MN value in the landscape studied here is considered low.

We verified the presence of a large patch observed in the study area, which is of critical importance for the maintenance of local species because there is a correlation between population dynamics, the relative quality of the habitat and landscape structure. The Interior Forest region of the Atlantic Forest domain comprises a total area of 72784790 ha and has only one patch larger than 50,000 ha (Ribeiro et al. 2009).The largest patch found by Cemin et al. (2009) occupied a higher percentage of the landscape (9.27\%), while Calegari et al. (2010) found a lower value $(1.55 \%)$.

In comparison to Boscolo \& Metzger (2011) the mean patch isolation value was low. The former authors showed that less forested landscapes present higher mean isolation when compared to more forested ones. The study area had a higher number of small forest patches that correspond to a small portion of the natural vegetation. The occurrence of many small forest patches is common in the Atlantic Forest. Ranta et al. (1998) verified that $48 \%$ of the Atlantic Forest landscape patches in northeastern Brazil are smaller than 10 ha. Based on the modeled scenarios, we evaluated how these small patches would affect the landscape. The mean isolation increased considerably when the smaller patches were removed. Overall, we believe that small patches are important for reducing habitat isolation in all steps analyzed.

Even though small forest patches maintain plant populations of few individuals, frequently of the same species, thus sustaining the process of endogamy and increasing the probability of the extinction of local species (Costa 2003), their presence in the landscape is very relevant, especially when they function as stepping-stones facilitating the flow of species between the patches or when they promote an increased level of matrix heterogeneity and act as a refuge for species (Boscolo et al. 2008). Therefore, small patches, especially those close to large centers of biodiversity, have important functions in the landscape. In the long term, these areas may expand and become even more important.

We considered the incidence of small patches in Carmo de Minas essential for the conservation of local biodiversity and for the restoration of ecological integrity. The maintenance of these small patches scattered across the landscape plays an important ecological role in facilitating the flow of species through the landscape (Awade \& Metzger 2008; Boscolo et al. 2008) and reducing the isolation of larger

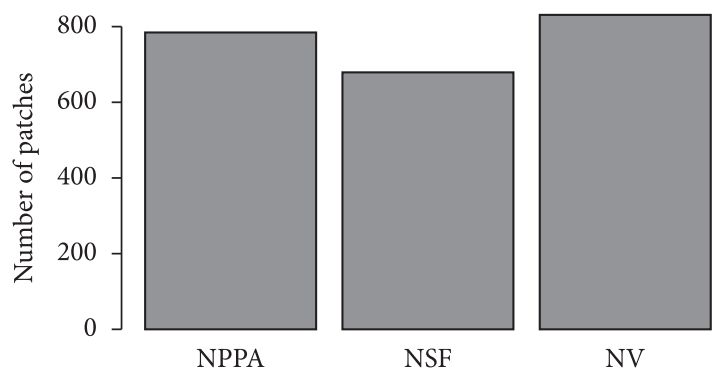

Figure 2. Comparison of the number of patches (NP) for vegetation/secondary forest (VSF), reforested vegetation/ permanent protected areas (VPPA) and the actual natural vegetation of the study area $\left(c^{2}=15.651, P<0.001\right)$.

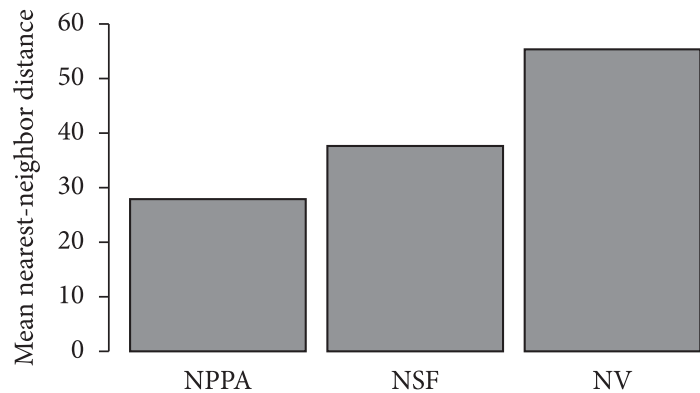

Figure 3. Comparison of the mean nearest-neighbor distance (ENN_MN) for vegetation/secondary forest (VSF), reforested vegetation/permanent protected areas (VPPA) and the actual natural vegetation of the study area $\left(c^{2}=9.653, P=0.008\right)$. 

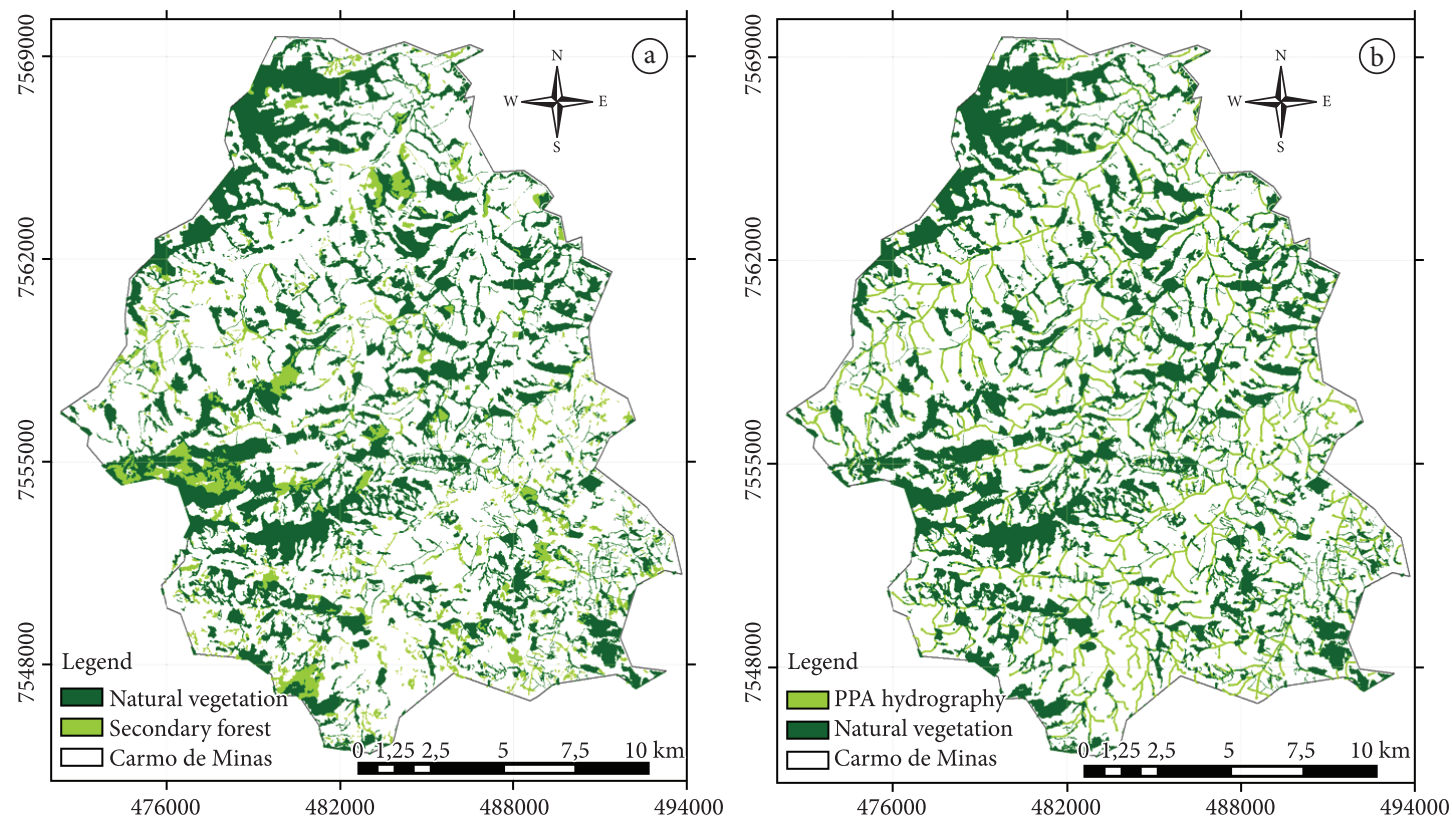

Figure 4. Landscape management scenarios of the study area: a) vegetation/secondary forest (VSF). b) reforested vegetation/ permanent protected areas (VPPA), including the strip marginal vegetation along the waterways and around the heads of rivers, known as Permanent Protection Areas (PPA) according to the Brazilian environmental legislation.

patches (Boscolo \& Metzger 2011), therefore ensuring a more permeable landscape (Ribeiro et al. 2009). If patches smaller than 10 ha were removed from the study landscape, approximately $90 \%$ of the remaining patches would be lost. This loss would compromise connectivity, increase patch isolation, and could even lead to the loss of numerous species.

\section{The landscape management scenarios}

The increase in the area of natural vegetation predicted for the VPPA scenario was higher than that predicted for the VSF (Figure 4). NP was significantly reduced in both scenarios as a result of the incorporation of new areas, which favored the clustering of patches to form larger units, as shown in Figure 2. This reduction may indicate that the effects of landscape fragmentation could be minimized in the VSF scenario. For the VPPA, the reduction in the number of patches was lower.

We observed a very significant increase in the AREA_MN in both scenarios, reflecting the area increase within the patches. Many species are associated only with the core areas of the patches and do not occur on the edges (Forman \& Godron 1986).

We found a significant decrease in patch isolation for both management landscapes scenarios (see Figure 3). This reduction may positively affect the mobility of numerous species that previously were notable to cross the matrix. If the distance between neighboring patches is reduced, certain bird species, for example, may be able to move between the patches (Awade \& Metzger 2008). According to Sick (1997), Baryphthengus ruficapillus (Vieillot, 1818) does not cross more than $30 \mathrm{~m}$ of open vegetation, for example.

In this sense, regrowth forests can play an important conservation role by enhancing landscape connectivity (Pardini et al. 2009). This was simulated in this study through the future scenarios. Both management scenarios increased the connectivity and reduced the isolation of natural vegetation remnants, favoring movement and survival of species. Due to the ecological importance of regrowth forests, ecologists and decision makers should pay more attention to this kind of forest and ensure they are maintained (Bowen et al. 2007). Initiatives promoting forest restoration (e.g. tree planting) following the proposal of these two models would improve environmental conservation and restoration in the study area.

\section{Conclusions}

The natural vegetation in the study area is highly fragmented, which compromises the conservation of biodiversity. The high number of small patches composing of the remnant vegetation is extremely important for reducing the isolation between the vegetation units. The future management scenarios provided a better understanding of the behavior of natural remnants in terms of their proximity and connectivity and allowed for an estimation of the future dynamics of the landscape.

We recommend vegetation rearrangement to enlarge the smaller patches and enhance their core areas and to 
delimit areas for permanent protection. Additionally, we recommend the maintenance of secondary forest areas and their restoration is also recommended to improve the integrity of the landscape.

\section{Acknowledgements}

We are very grateful to the staff of EPAMIG, to the CNPq for the financial support, and to Ricardo Solar for assistance in the statistical analysis.

\section{References}

Andrén H, 1994. Effects of habitat fragmentation on birds and mammals in landscapes with different proportions of suitable habitat: a review. Oikos, 71:355-366. http://dx.doi. org/10.2307/3545823

Awade M \& Metzger JP, 2008. Using gap-crossing capacity to evaluate functional connectivity of two Atlantic Rainforest birds and their response to fragmentation. Austral Ecology, 33:863-871. http://dx.doi. org/10.1111/j.1442-9993.2008.01857.x

Bender DJ, Tischendorf L \& Fahrig L, 2003. Using patch isolation metrics to predict animal movement in binary landscapes. Landscape Ecology, 18:17-39. http://dx.doi. org/10.1023/A:1022937226820

Boscolo D \& Metzger JP, 2011. Isolation determines patterns of species presence in highly fragmented landscapes. Ecography. 34:1-12. http://dx.doi. org/10.1111/j.1600-0587.2011.06763.x

Boscolo D et al., 2008. Importance of inter-habitat gaps and stepping-stones for lesser woodcreepers (Xiphorhynchus fuscus) in the Atlantic Forest, Brazil. Biotropica, 40:273-276. http://dx.doi.org/10.1111/j.1744-7429.2008.00409.x

Brasil. Lei no 4.771 , de 15 de Setembro de 1965. Institui o novo Código Florestal. Diário Oficial da República Federativa do Brasil, Brasília (1965 set.16). Seção 1. Available from: $<$ http://www.mma.gov.br/sitio/index.php?ido=legislacao. index\&tipo=1>. Access in: 20 sep. 2009.

Bowen ME et al., 2007. Regrowth forests on abandoned agricultural land: a review of their habitat values for recovering forest fauna. Biological Conservation, 140:273-296. http://dx.doi.org/10.1016/j.biocon.2007.08.012

Calegari L et al., 2010. Análise da dinâmica de fragmentos florestais no município de Carandaí, MG, para fins de restauração florestal. Árvore, 34:871-880.

Câmara G et al., 1996. Spring: integrating remote sensing and GIS by object-oriented data modeling. Computers \& Graphics, 20:395-403. http://dx.doi. org/10.1016/0097-8493(96)00008-8

Cemin G, Perico E \& Rempel C, 2009. Composição e configuração da paisagem da sub-bacia do arroio Jacaré, Vale do Taquari-RS, com ênfase nas áreas de florestas. Árvore, 33:705-711.

Cohen J, 1960. A coefficient of agreement for nominal scales. Educational and Psychological Measurement, 20:37-46. http://dx.doi.org/10.1177/001316446002000104
Costa RB, 2003. Fragmentação florestal e alternativas de desenvolvimento rural na região Centro-Oeste. Campo Grande: UCDB. 246 p.

Fahrig, L. 2003. Effects of habitat fragmentation on biodiversity. Annual Reviews of Ecology and Systematics, 34:487-515. http://dx.doi.org/10.1146/annurev.ecolsys.34.011802.132419

Fischer J \& Lindenmayer DB, 2007. Landscape modification and habitat fragmentation: a synthesis. Global Ecology and Biogeography, 16:265-280. http://dx.doi. org/10.1111/j.1466-8238.2007.00287.x

Forman RTT \& Godron M, 1986. Landscape ecology. New York: J. Wiley. 620 p.

Gardner TA, 2010. Monitoring forest biodiversity: improving conservation through ecologically-responsible management. London: Earthscan. 388 p.

Instituto Brasileiro de Geografia e Estatística - IBGE, 2009. Cities. Rio de Janeiro. Available from: <ftp://geoftp.ibge. gov.br/MME2007/MG/CARMO\%20DE\%20MINAS.pdf>. Access in: 10 jun. 2009

Kageyama PY, Gándara FB \& Oliveira RE, 2003. Biodiversity andrestoration of the tropical forest. In: Kageyama PY, Gándara FB, Oliveira RE. Ecological Restoration of Natural Ecosystems. São Paulo: Foundationfor Studies and Researchfor Agriculture and Forestry. p. 29-46.

Martins CS, 2000. Caracterização física e fitogeográfica de Minas Gerais. In: Mendonça MP, Lins LV. Lista vermelha das espécies ameaçadas de extinção da flora de Minas Gerais. Belo Horizonte: Fundação Biodiversitas, 2000. p. 35-43.

McGarigal KSA \& Marks BJ, 1995. Fragstats: spatial pattern analysis program for quantifying landscape structure. Portland: U.S. Forest Service General Technical Report. 141 p.

Metzger JP, 2006. Estrutura da paisagem: uso adequado de métricas. In: Cullen-Junior L, Pádua CV \& Rudy R. Métodos de estudos em biologia da conservação e manejo da vida silvestre. 2. ed. Curitiba: UFPR. p. 423-453.

Metzger JP \& Décamps H, 1997. The structural connectivity threshold: an hypothesis in conservation biology at the landscape scale. Acta Ecologica. 18:1-12. http://dx.doi. org/10.1016/S1146-609X(97)80075-6

Murcia C, 1995. Edge effects in fragmented forests: implications for conservation. Trends in Ecology and Evolution, 10:58-62. http://dx.doi.org/10.1016/S0169-5347(00)88977-6

Norris K, 2008. Agriculture and biodiversity conservation: Opportunity knocks. Conservation Letters, 1:2-11. http:// dx.doi.org/10.1111/j.1755-263X.2008.00007.x

Pardini R et al., 2009. The challenge of maintaining Atlantic Forest biodiversity: a multi-taxa conservation assessment of specialist and generalist species in an agro-forestry mosaic in southern Bahia. Biological Conservation, 142:1178-1190. http://dx.doi.org/10.1016/j.biocon.2009.02.010

R Development Core Team, 2011. R: A language and environment for statistical computing. Vienna: R Foundation for Statistical Computing. Available from: <http://www.R-project.org/>.

Ranta P et al., 1998. The fragmented Atlantic rain Forest of Brazil: size, shape and distribution of Forest fragments. 
Biodiversity and Conservation, 7:385-403. http://dx.doi. org/10.1023/A:1008885813543

Ribeiro MC et al., 2011. The Brazilian Atlantic Forest: a shrinking biodiversity hotspot. In: Zachos FE \& Habel JC (eds.). Biodiversity Hotspots. Berlin; Heidelberg: Springer-Verlag. part 4, p. 405-434. http://dx.doi. org/10.1007/978-3-642-20992-5_21

Ribeiro MC et al., 2009. The Brazilian Atlantic Forest: how much is left, and how is the remaining forest distributed? implications for conservation. Biological Conservation, 142:1141-1153. http://dx.doi.org/10.1016/j. biocon.2009.02.021

Ricketts TH, 2001. The matrix matters: effective isolation in fragmented landscapes. The American Naturalist, 158:87-99. PMid:18707317. http://dx.doi.org/10.1086/320863
Saunders DA, Hobbs RJ \& Margules CR, 1991. Biological consequences of ecosystem fragmentation: a review. Conservation Biology, 5:18-32. http://dx.doi. org/10.1111/j.1523-1739.1991.tb00384.x

Sick H, 1997. Ornitologia brasileira. Rio de Janeiro: Nova Fronteira.

Scolforo JRS \& Carvalho LMT, 2006. Mapeamento e inventário da flora nativa e dos reflorestamentos em Minas Gerais. Lavras: UFLA. 288 p.

Turner MG \& Gardner RH, 1990. Quantitative methods in landscape ecology: the analysis and interpretation of landscape heterogeneity. New York: Springer Verlag, 536 p.

Veloso HP, Rangel-Filho ALR \& Lima JCA, 1991. Classificação da vegetação brasileira adaptada a um sistema universal. Rio de Janeiro: IBGE. 123 p.

Received: August 2011

First Decision: January 2012

Accepted: May 2012 